\title{
The Possible Contribution of being Born by Cesarean Section to Developing Childhood Overweight and Obesity in Later Life
}

\section{A possível contribuição do nascimento por cesariana para o desenvolvimento do excesso de peso infantil e da obesidade na vida posterior}

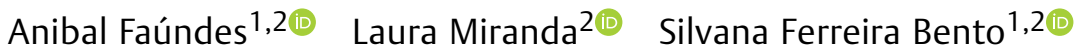 \\ ${ }^{1}$ Department of Obstetrics and Gynecology, Universidade Estadual de \\ Campinas, Campinas, São Paulo, Brazil \\ ${ }^{2}$ Campinas Centre for Research in Human Reproduction (Cemicamp), \\ Address for correspondence Anibal Faúndes, MD, Rua Vital Brasil, \\ 200, 13083-888, Cidade Universitária, Campinas, SP, Brazil \\ (e-mail: afaundes@uol.com.br).
} Campinas, São Paulo, Brazil

Rev Bras Ginecol Obstet 2021;43(6):487-489.

\section{Introduction}

Obesity is now a major global epidemic. In 2016, 39\% of adults worldwide $\geq 18$ years old were overweight, and $13 \%$ were obese, as reported by the World Health Organization (WHO). ${ }^{1}$ This current scenario is compounded in highincome countries such as the United States, where $31 \%$ of the population has a body mass index (BMI) $>30 \mathrm{~kg} / \mathrm{m}^{2}$ and $50 \%$ have a waist circumference $\geq 88 \mathrm{~cm}$, in the case of women, or $\geq 102 \mathrm{~cm}$ in the case of men. ${ }^{2}$ Overweight and obesity are rapidly becoming a major health issue, as these conditions are associated with severe chronic diseases such as diabetes, hypertension, and cardiovascular diseases in general. ${ }^{3}$

While it is largely agreed that obesity and overweight are the consequences of an unhealthy diet, mainly due to an increasing use of processed and preserved foods together with minimal physical activity, an association between cesarean delivery and obesity in later life has also been suggested. Cesarean section rates continue to increase well beyond what could be medically justified, and several studies conducted in different countries have found an association between being born by cesarean section and developing obesity in childhood or adulthood. ${ }^{4}$

\section{Cesarean Section and the Development of Overweight and Obesity}

The Growing Up Today Study (GUTS), a large prospective study of individuals followed-up from childhood through early

DOI https://doi.org/ 10.1055/s-0041-1731381. ISSN 0100-7203. adulthood in the United States, evaluated obesity as defined by the cutoff limit of BMI $\geq 30 \mathrm{~kg} / \mathrm{m}^{2}$, in accordance with the WHO criteria. The multivariate adjusted risk ratio (RR) for obesity was 1.15 for infants delivered by cesarean section compared with those born by vaginal delivery ( $95 \%$ confidence interval [CI]: 1.06-1.26; $p=0.002$ ). The multivariate adjusted RR for obesity according to age group was: 1.23 (95\%Cl: 1.03-1.46) at ages between 9 and 12 years old, 1.16 (95\%CI: $1.03-1.31)$ at ages between 13 and 18 years old, and 1.10 (95\% CI: $0.98-1.24$ ) at ages between 19 and 24 years old ( $p$-value for heterogeneity $=0.13$ ). The associations were similar both for females (1.12; 95\%CI: 0.99-1.27) and for males (1.18; 95\%CI: $1.04-1.34)(p \text {-value for heterogeneity }=0.62)^{5}$

Three birth cohorts in the Brazilian city of Pelotas, state of Rio Grande do Sul, were followed-up into adulthood using a very similar methodology. All babies born in 1982, 1993 and 2004 whose mothers lived in the city were recruited to the studies. Fat mass index and BMI z-scores in the offspring were strongly and positively associated with cesarean birth in the crude analysis. However, following adjustment for socioeconomic characteristics and maternal factors such as BMI, parity, age, and smoking during pregnancy, the association disappeared, except for the group of 30-year-old women. In these women from the 1982 cohort, cesarean section remained associated with fat mass index $(\beta=0.82 ; 95 \% \mathrm{CI}$ : $0.32-1.32)$ and BMI $z$-score $(\beta=0.15$; $95 \% \mathrm{Cl}: 0.03-0.28)$.

(c) 2021. Federação Brasileira de Ginecologia e Obstetrícia. All rights reserved.

This is an open access article published by Thieme under the terms of the Creative Commons Attribution License, permitting unrestricted use, distribution, and reproduction so long as the original work is properly cited. (https://creativecommons.org/licenses/by/4.0/)

Thieme Revinter Publicações Ltda., Rua do Matoso 170, Rio de Janeiro, RJ, CEP 20270-135, Brazil 
Following adjustment for potential confounders, the association persisted, indicating higher fat mass index and BMI at the age of 30 years old in those born by cesarean section compared with those delivered vaginally. ${ }^{6}$

The Project Viva enrolled participants between April 1999 and July 2002 in eastern Massachusetts, USA, forming a longitudinal prebirth cohort of mother-offspring pairs. In the children delivered by cesarean section, there was a 2 -fold likelihood of developing obesity, with a higher BMI $(\sim 0.2 \mathrm{z}-$ score units higher) and higher sum of triceps plus subscapular skinfold thicknesses $(\sim 1 \mathrm{~mm})$ at the age of 3 years old compared with children delivered vaginally. These differences between the two modes of delivery persisted following adjustment for key potential confounding factors including maternal BMI and birthweight. ${ }^{7}$

In South Africa, an analysis of young adults aged between 21 and 24 years old from a longitudinal urban birth cohort showed that having been born by cesarean section was associated with obesity in early adulthood. In the crude analysis, birth by cesarean section was associated with an almost 2-fold increase in the risk of obesity among young people between 21 and 24 years old. Following adjustment for gender, birthweight, and the mother's parity and education level at delivery as possible confounders, the strength of the association was maintained. ${ }^{8}$

No such association was found, however, in a large, contemporary, prospective, longitudinal cohort study, the Millennium Cohort Study (MCS), conducted in the United Kingdom, which found no statistically significant difference in BMI at the ages of 3 and 14 years old in infants born by planned cesarean section compared with those born by vaginal delivery. Furthermore, there was no difference in body fat percentage at 7 and 14 years old between infants born by planned cesarean section and those born by vaginal delivery. ${ }^{9}$

A very large systematic review and meta-analysis conducted to investigate associations between mode of delivery and adult BMI, overweight, and obesity found that the mean BMI was $0.44 \mathrm{~kg} \cdot \mathrm{m}^{-2}$ greater in subjects delivered by cesarean section compared with those delivered vaginally. The increased odds of overweight and obesity $>20 \%$ applied to both genders. ${ }^{10}$

\section{The Role of the Gut Microbiome as a Mechanism of Action in Overweight and Obesity}

As accumulated global experience appears to confirm the association between being born by cesarean section and overweight and obesity in later life, a possible explanation for this association may lie in the limited microbial diversity reported in offspring delivered by cesarean section compared with that of those born by vaginal delivery. ${ }^{11,12}$ Infants born by vaginal delivery are exposed to microorganisms mainly in the birth canal or in the vaginal environment, while those delivered by cesarean section are exposed to microflora on the mother's skin. ${ }^{13}$ This is presumed to persist into adulthood. ${ }^{5}$
Experiments in rodents have shown the important role of microorganisms in the mechanism of obesity. Transferring fecal microbial content from normally raised mice to adult germ-free mice leads to a very rapid and voluminous increase in body fat within between 10 and 14 days, even when food consumption is reduced. ${ }^{14}$ There are several mechanisms involved in these changes, including microbial fermentation of dietary polysaccharides that cannot be digested by mice, the contribution of monosaccharide and fatty acids to intestinal absorption, their metabolism in the liver, and the regulation of host genes that promote the deposition of lipids in adiposity. ${ }^{14}$

Infants delivered by cesarean section, particularly elective cesarean section, are generally not exposed to their mother's vaginal and fecal microbiota, which helps shape the initial composition of an infant's gut microbiota. ${ }^{13}$ The diverseness and richness of their gut microbiome has been found to be poor. ${ }^{15}$ According to some studies, the gut microbiota of infants born by cesarean section may have a tendency to harvest more dietary nutrients, thus predisposing them to being overweight or obese. ${ }^{16,17}$

\section{Conclusion}

Although the effect of the rise in the number of cesarean sections on the increasing rates of overweight and obesity may be minimal, it would nonetheless appear to constitute one more factor contributing to obesity, a worldwide health concern.

\section{Contributions}

Faúndes A. and Miranda L. had the original idea of revising the subject, based on isolated observation and in a revision of articles on microbioma. Faúndes A., Miranda L. and Bento S. F. reviewed the literature, selected the appropriate article, and summarized the results. Faúndes A., Miranda L. and Bento S. F. contributed to the writing of the final paper.

Conflict of Interests

The authors have no conflict of interests to declare.

\section{References}

1 World Health Organization. Obesity and overweight: Fact sheet [Internet]. 2020. [cited 2020 Nov 25]. Available from: https://www.who.int/news-room/fact-sheets/detail/obesity-andoverweight

2 Miranda JJ, Herrera VM, Chirinos JA, Gómez LF, Perel P, Pichardo R, et al; The Latin American Consortium of Studies in Obesity (LASO) Major cardiovascular risk factors in Latin America: a comparison with the United States. PLoS One. 2013;8(01):e54056. Doi: 10.1371/journal.pone.0054056

3 Whitlock G, Lewington S, Sherliker P, Clarke R, Emberson J, Halsey J, et al; Prospective Studies Collaboration. Body-mass index and cause-specific mortality in 900000 adults: collaborative analyses of 57 prospective studies. Lancet. 2009;373(9669):1083-1096. Doi: 10.1016/S0140-6736(09)60318-4

4 Betrán AP, Ye J, Moller AB, Zhang J, Gülmezoglu AM, Torloni MR. The increasing trend in caesarean section rates: global, regional 
and national estimates: 1990-2014. PLoS One. 2016;11(02): e0148343. Doi: 10.1371/journal.pone.0148343

5 Yuan C, Gaskins AJ, Blaine AI, Zhang C, Gilman MW, Missmer SA, et al. Association between cesarean birth and risk of obesity in offspring in childhood, adolescence and early adulthood. JAMA Pediatr. 2016; 170(11):e162385. Doi: 10.1001/jamapediatrics.2016.2385

6 Barros AJ, Santos LP, Wehrmeister F, Motta JVS, Matijasevich A, Santos IS, et al. Caesarean section and adiposity at 6,18 and 30 years of age: results from three Pelotas (Brazil) birth cohorts. BMC Public Health. 2017;17(01):256. Doi: 10.1186/s12889-017-4165-3

7 Huh SY, Rifas-Shiman SL, Zera CA, Edwards JWR, Oken E, Weiss ST, et al. Delivery by caesarean section and risk of obesity in preschool age children: a prospective cohort study. Arch Dis Child. 2012;97 (07):610-616. Doi: 10.1136/archdischild-2011-301141

8 Sogunle E, Masukume G, Nelson G. The association between caesarean section delivery and later life obesity in 21-24 year olds in an Urban South African birth cohort. PLoS One. 2019;14 (11):e0221379. Doi: 10.1371/journal.pone.0221379

9 Masukume G, Khashan AS, Morton SMB, Baker PN, Kenny LC, McCarthy FP. Caesarean section delivery and childhood obesity in a British longitudinal cohort study. PLoS One. 2019;14(10): e0223856. Doi: 10.1371/journal.pone.0223856

10 Darmasseelane K, Hyde MJ, Santhakumaran S, Gale C, Modi N. Mode of delivery and offspring body mass index, overweight and obesity in adult life: a systematic review and meta-analysis. PLoS One. 2014;9(02):e87896. Doi: 10.1371/journal.pone.0087896

11 Zhou X, Brown CJ, Abdo Z, Davis CC, Hansmann MA, Joyce P, et al. Differences in the composition of vaginal microbial communities found in healthy Caucasian and black women. ISME J. 2007;1(02): 121-133. Doi: 10.1038/ismej.2007.12

12 Penders J, Thijs C, Vink C, Stelma FF, Snijders B, Kummeling I, et al. Factors influencing the composition of the intestinal microbiota in early infancy. Pediatrics. 2006;118(02):511-521. Doi: 10.1542/ peds.2005-2824

13 Dominguez-Bello MG, Costello EK, Contreras M, Magris M, Hidalgo G, Fierer N, et al. Delivery mode shapes the acquisition and structure of the initial microbiota across multiple body habitats in newborns. Proc Natl Acad Sci U S A. 2010;107(26):11971-11975. Doi: 10.1073/pnas.1002601107

14 Bäckhed F, Ding H, Wang T, Hooper LV, Koh GY, Nagy A, et al. The gut microbiota as an environmental factor that regulates fat storage. Proc Natl Acad Sci U S A. 2004;101(44):15718-15723. Doi: $10.1073 /$ pnas.0407076101

15 Azad MB, Konya T, Maughan H, Guttman DS, Field CJ, Chari RS, et al; CHILD Study Investigators. Gut microbiota of healthy Canadian infants: profiles by mode of delivery and infant diet at 4 months. CMAJ. 2013;185(05):385-394. Doi: 10.1503/ cmaj.121189

16 Turnbaugh PJ, Ley RE, Mahowald MA, Magrini V, Mardis ER, Gordon JI. An obesity-associated gut microbiome with increased capacity for energy harvest. Nature. 2006;444(7122):1027-1031. Doi: $10.1038 /$ nature 05414

17 Jumpertz R, Le DS, Turnbaugh PJ, Trinidad C, Bogardus C, Gordon JI, et al. Energy-balance studies reveal associations between gut microbes, caloric load, and nutrient absorption in humans. Am J Clin Nutr. 2011;94(01):58-65. Doi: 10.3945/ajcn.110.010132 